\title{
Stratejik Yenilik Yönetiminin İşe Adanmışlık Üzerine Etkisi: Aile Şirketlerinde Bir Araştırma (The Effect of Strategic Innovation Management on Commitment: A Study in Family Businesses)
}

\section{Mesut KASAP iD a}

a Çanakkale Onsekiz Mart Üniversitesi, Sosyal Bilimler Meslek Yüksek Okulu, Çanakkale, Türkiye. mesutkasap25@gmail.com

\section{MAKALE BİLGÍSI \\ Anahtar Kelimeler: \\ Stratejik yenilik yönetimi \\ Inovasyon \\ İşe adanmışlık \\ Marmara Bölgesi \\ Aile şirketleri \\ Gönderilme Tarihi 17 Ekim 2020 \\ Revizyon Tarihi 2 Aralık 2020}

Kabul Tarihi 20 Aralık 2020

Makale Kategorisi:

Araştırma Makalesi

\section{ÖZET}

Amaç - Bu araştırmanın amacı stratejik yenilik yönetiminin işe adanmışlık üzerine etkisini belirlemektir.

Yöntem - Araştırmada nicel araştırma modellerinden ilişkisel tarama modeli kullanılmıştır. Araştırmanın evrenini Marmara Bölgesindeki aile şirketleri oluşturmaktadır. Araştırmanın örneklem grubunu ise bu şirketlerdeki çalışanlar oluşturmaktadır. Araştırmada İşe Adanmışlık Ölçeği ve Stratejik İnovasyon Ölçeği kullanılmıştır. Araştırmada verileri analiz etmek amacıyla tanımlayıcı istatistiksel analizleri, t-testi, ANOVA, korelasyon, Regresyon analizleri kullanılmıştır.

Bulgular - Araştırmaya katılan çalışanların yenilik stratejisi, örgüt yapısı, inovasyon kültürü, teknoloji yeteneği, müşteri ve tedarikçilerle ilişkiler konusunda olumlu düşündükleri görülmektedir. Araştırmaya katılan çalışanlar, başarısızlıkları öğrenme fırsatı olarak gördüklerini, teknolojideki yeni gelişmeleri izlediklerini, resmi iletişimi kolaylaştırmak amacıyla çalışma yapıldığını, ilerleme eylem planlarının olduğunu ifade etmektedirler. Araştırma katılımcıları yöneticilerin teknolojik hedeflerin yeni fikirlerin değerlendirilmesine rehberlik ettiğini, işletmenin itibarının önemli olduğunu, tedarikçilerin ve müşterilerin bu süreçte önemli olduklarını belirtmektedirler. Araştırma örneklem grubunun cinsiyetleriyle, stratejik inovasyon ve işe adanmışlık düzeyleri arasında anlamlı bir ilişkinin olmadığı görülmektedir. Araştırmaya katılanların mesleki kıdemleriyle yenilik stratejisi arasında bir ilişkinin olduğu görülmektedir. Araştırmaya katılan çalışanların stratejik inovasyon ile ilgili görüşleriyle işe adanmışlık ile ilgili görüşleri arasında pozitif yönlü yüksek düzeyde bir ilişkinin olduğu görülmektedir.

Tartışma - İşe adanmışlıkla stratejik inovasyon arasında anlamlı bir ilişki olduğu, işe adanmışlığın stratejik inovasyonun anlamlı bir yordayıcısı olduğu görülmüştür. Araştırmanın bulguları stratejik yenilik yönetiminin işe adanmışlık ile güçlü bir bağının olduğunu ortaya koymaktadır. Ayrıca araştırmada stratejik yenilik yönetiminin çalışanlar üzerinde önemli bir etkisinin olduğu görülmüştür.

\section{ARTICLE INFO}

\section{ABSTRACT}

\section{Keywords:}

Strategic innovation management

Innovation

Commitment to business

Marmara Region

Family companies

Received 17 October 2020

Revised 2 December 2020

Accepted 20 December 2020

Article Classification:

Research Article
Purpose - The purpose of this research is to determine the effect of strategic innovation management on commitment.

Design/methodology/approach - In the research, relational scanning model, one of the quantitative research models, was used. Family companies in the Marmara Region constitute the universe of the research. The sample group of the research is the employees in these companies. Commitment to Work Scale and Strategic Innovation Scale were used in the study. Descriptive statistical analyzes, t-test and ANOVA, correlation and regression analysis were performed on the data obtained in the study.

Findings - It is seen that the employees participating in the study think positively about innovation strategy, organizational structure, innovation culture, technology ability, relations with customers and suppliers. They state that the employees participating in the research see failures as an opportunity to learn, they follow new developments in technology, studies are carried out to facilitate formal communication, and there are action plans for progress. Research participants state that managers' technological goals guide the evaluation of new ideas, the reputation of the enterprise is important, suppliers and customers are important in this process. It is observed that there is no significant relationship between the gender of the research sample group and the levels of strategic innovation and commitment to work. It is seen that there is a relationship between the professional seniority of the participants and the innovation strategy. It is observed that there is a high-level positive relationship between the views of the employees participating in the study on strategic innovation and their views on commitment to work.

Discussion - It was observed that there was a significant relationship between commitment to work and strategic innovation, and that commitment to work was a significant predictor of strategic innovation. The findings of the study reveal that strategic innovation management has a strong link with business commitment. In addition, it was seen in the research that strategic innovation management has a significant effect on employees. 


\section{Giriş}

Küreselleşmeye bağlı olarak bilginin çok hızlı bir şekilde yayılması işletmeleri stratejik yenilikler yapmaya zorlamaktadır. İşletmeler için mevcut pozisyonlarını korumanın ve farklı pazarlardan pay almanın yolu, yeni hizmet/ürün ve stratejik yenilikten geçmektedir. Bu durumda işletmelerin rekabet üstünlüğüne sahip olabilmesini yenilikçi hizmet/ürün ve süreç yönetiminden ve kalite sayesinde artıracağı performansına bağlı hale getirmiştir. Rakiplerine oranla farklı değerler yaratarak stratejik yenilik yönetimi sergileyen işletmeler, daha kârlı faaliyetlerde bulunacaklardır. Rekabetin zorlaşması, teknolojideki ilerleyiş ve kalitenin işletmeler için belirleyici olduğu gerçeğinden hareketle; müşteri beklentilerine karşıllk verebilmek için işletmelerin fark yaratması gerekmektedir (Altınkurt, 2007; Aydın ve Bekmezci, 2020; Güçlü, 2003).

Stratejik yenilik örgütler açısından son derece önemli bir olgudur. İşletmenin rekabet ortamında etkili stratejiler uygulayabilmesi için yenilik performansını arttırması gerekmektedir. Yenilik performansı; işletmenin iç unsurları, rekabet üstünlügü̈, girişimcilik ve yenilik stratejileriyle ilişkili bir kavramdır (Balkı, İlhan ve Özkoç, 2020).

İşletmeler sürdürülebilir rekabet üstünlügü kazanarak günümüz dünyasında hayatta kalabilmektedir. Sürdürülebilir rekabet üstünlüğü de işletmenin her alanında yenilik yapmasıyla mümkündür. Bu bağlamda stratejik yenilik yönetiminin, işletmeye değişen koşullara ayak uyduracak rekabet yeteneği ve belirsizlik ortamlarında işletmenin fırsatları yakalaması gibi avantajları söz konusudur (Akgemcï, Öğüt ve Ay Tosun, 2000; Atherton ve Hannon 2000; Örücü, Kılıç ve Savaş, 2011).

İşletmeler tarihsel süreçte yeniliklere ayak uydurmak için birçok radikal değişiklik yapmıştır. Rekabet şartlarındaki değişimler, özellikle fark yaratan ürünleri müşteriye sunabilmenin avantaj yarattığını göstermektedir. Yine yenilik stratejilerinin başarısı da vurgulanmaktadır (Deniz, 2011). Stratejik yeniliğin işletme paydaşlarına uzun dönemde rekabet avantajı sağladığı görülmektedir (Güleş ve Bülbül, 2004). Genel olarak yenilik türleri şu şekildedir (Bielinis, 2004: 17; Gray ve Allan, 2001);

$\checkmark$ Yeni bir hizmet/ürün ve ya üründeki niteliksel gelişimler

$\checkmark$ Üretimde yeni yöntemler geliştirme

$\checkmark$ Pazarlama yönteminde stratejik yenilik yapma

$\checkmark$ Bütün kaynakların tedarikinde yeni kaynaklar geliştirme

$\checkmark$ Organizasyon yapılarında yenilikler

İşletmeler küreselleşmeyle zorlaşan rekabet ortamına ayak uydurmaya çalışmaktadır. Uluslararası düzeyde rekabet avantajı sağlamak yerel rekabet ortamına oranla daha büyük bir anlam ifade ettiği için bu duruma uygun stratejiler belirlemelidir. Porter (1981) sürdürülebilir rekabet üstünlüğü elde edebilmenin yolunun yenilik yapma, gelişim ve değişim olduğunu ifade etmiştir. Uluslararası anlamda işlerin yapılma şekilleri değişmektedir (Ventura ve Soyuer, 2016). Buna bağlı olarak işletmelerin de değişimlere uygun önlemler alacak stratejik yenilikleri yapması gerekmektedir. Değişimlere direnen ya da değişim yapmakta geciken işletmeler, büyük zararlara uğrayarak kaybolmaya yüz tutmaktadır. Bu yüzden güncel olan ve geçerliliği kabul gören değişimlerin işletmenin menfaatine olacak şekilde örgüte kazandırılması gerekmektedir (Mert, 2020; Özaydın ve Çelik, 2020; Shibu ve Uysal, 2020).

Genel olarak işletmelerin rakiplerinden farklı olduğunu göstermesi ve müşteri memnuniyeti için sürekli yenilik yapmak zorunda olması araştırmaların en önemli vurgu noktasıdır. İşletme yenilik yapıyorsa, olumsuz çevre şartlarından az etkilenecek ve zorlaşan rekabet koşullarında hayatta kalması mümkün olacaktır. Aynı zamanda yenilik performansını arttıran işletmeler, daha iyi ürün/hizmet sunarak amaçlarına ulaşmada avantaj elde edecektir. Örgütlerin rakiplerine üstünlük sağlayacağı nokta, yenilik performansıdır. Örgütlerin yenilik performanslarını arttırmaları için önemli bazı faktörler belirtilmiştir. Bunlar (Kale, 2010):

$\checkmark \quad$ Işletme yapısı

$\checkmark$ Teknik iş gücü

$\checkmark$ İşletme kaynakları

$\checkmark \quad$ İşletmenin çeşitli bağlantıları 
İşletmelerde yenilik sadece içsel bir durum değil, iç çevre ve dış çevre analizi gerektiren bir durumdur. İşletmedeki bütün departmanlar yenilik konusunda birlikte hareket etmelidir. İç analizde işletmenin gerek duyduğu yenilik ortaya konulurken, rakip işletmelerin güçlü yönlerini bilmek de diş analiz ile mümkündür (Kendir, Arslan ve Özçelik Bozkurt, 2018; Özbağ, 2010). Yenilik performansının ortaya konmasında öznel ve nesnel ölçümler söz konusudur. Öznel ölçüme örnek vermek gerekirse, işletme çalışanlarının motivasyonlarını arttıran yönetsel kararlar ve çalışan devir hızı olarak ifade edilebilir. Nesnel ölçüme örnek ise, işletmenin rakip firmalarla karşılaştırıldığındaki durumudur. Yönetici kararları çalışan motivasyonunu arttırmakta, bu da yenilikçi örgüt yapısını oluşturmaktadır. Yöneticilerin yenilikçi örgüt yapısı oluşturması, işe adanmışlıkla yakından ilişkili bir durumdur (Balkı, İlhan ve Özkoç, 2020).

İşletmelerin stratejik yenilikçi özelliklerinin devamı için çalışan motivasyonu ve buna bağlı olarak performansları yüksek olmalıdır. Çünkü iyi bir çalışma ortamı sunan işletmelerde, yüksek verimliliğin olacağı bilinmektedir. Sağlıklı bir çalışma ortamı olduğu zaman çalışanlar işlerine daha bağlı hale gelerek yenilik üretebileceklerdir. İşte burada işe adanmışlık konusu ortaya çıkmaktadır. İşe adanmışlık, özellikle son zamanlarda bütün örgütlerin çalışanlarından beklediği bir olgu olarak bireylerin karşısına çıkmaktadır. İşe adanmışlık, örgüt içerisinde faaliyette bulunan çalışanın psikolojik ve fiziksel olarak işindeki enerjisi olarak tanımlanmaktadır (Rich, Crawford ve Lepine, 2010).

İş ortamı sağlıklı olan işletmelerde, işe adanmışlık söz konusudur. İşe adanmış çalışanlar, işletmedeki diğer çalışanlara oranla daha yüksek verimlilikte çalışmaktadır. Yine işe adanmış çalışanlar, kişisel gelişimine önem verdiği için yenilikleri takip ederek örgütün amaçlarına ulaşmasında fark yaratacak etkiyi sergilemektedirler (Yıluzar, 2016). Bundan ötürü işine kendini adamış bir çalışanın yeniliklere açık hale geleceği ve işletmedeki diğer çalışanlardan daha verimli bir performans göstereceği bilinmektedir.

İşe adanmışlık, bireyin iş ortamında sorumlu olduğu görevleri arzulu bir şekilde kusursuzu hedefleyerek yapmasıdır (Harzer ve Ruch, 2014: 187; Uysal, Özçelik ve Uyargil, 2018). İşe adanmış çalışanlar; psikolojik olarak hazır, işletmeye bağlı, verilen bütün görevleri en yüksek verimlilikle yerine getirmeye hevesli ve farklı çözüm yöntemlerine başvuracak tarzda bir davranış sergiler. İşe adanmış çalışanlar; bulunduğu ortama değişiklik katarak, yeniliklerin ortaya çıkmasını sağlarlar (Esen, 2011: 377). Yine işe adanmış bireyler, pozitif duygular içerisinde her şeyin üstesinden geleceğine inanarak hareket ederler (Bostancı ve Ekiyor, 2015: 39; Karataş ve Aktaş, 2019).

İşe adanmışlıkta çalışanlar, kendilerini işleriyle özdeşleştirmek istemektedirler. Yaptıkları işlere kendilerini fiziksel, duygusal ve zihinsel olarak adamış olmaları gerekmektedir (Kahn, 1990: 693; Tecimen, 2020). İşe adanmışlık üç farklı şekilde belirtilmiştir;

$\checkmark$ Fiziksel Adanmışlık

$\checkmark$ Duygusal Adanmışlık

$\checkmark$ Zihinsel (Bilişsel) Adanmışlık

İşe adanmışlık olgusunun ortaya çıkmasında Kahn (1992) çok büyük katkı sunmuştur. Kahn, işe adanmışlık durumunun işletme içerinde olabilmesi için üç psikolojik noktanın altını çizmiştir. Bunlar uygunluk, anlamlılık ve güvenliktir. Bu üç psikolojik sürecin olması halinde çalışanların işlerine kendilerini adama durumu ortaya çıkmaktadır. Aksi takdirde böyle bir durumun varlığından bahsedilemeyeceğini vurgulamıştır. Özellikle Kahn, çalışanların işlerini anlamlı bulduğu zaman, işletmede kendini güvende hissettiğin de ve iş için yeterli olduğu inancı oluştuğunda işe adanmışlık durumu oluşacağını belirtmiştir (Khan, 1992: 322). Yapılan araştırma da Kahn'ın önerisi olan bu modellemeyi test edilmiş ve iş görenlerin anlamlılık, güvenlik ve uygunluk durumlarının işe adanmışlık durumlarılya ilişkisini ortaya konulmuştur (May, Gilson ve Harter, 2004: 29-30). Konuların daha iyi anlaşılması için stratejik yenilik yönetiminin işe adanmışlıkla olan ilişikisi literatür taraması yapılarak anlatılacaktır.

\subsection{Stratejik Yenilik ve İşe Adanmışlık Arasındaki İlişki}

İşe adanmışlığın yukarıda belirtildiği gibi fiziksel, zihinsel (bilişsel) ve duygusal olmak üzere üç boyutu bulunmaktadır. Fiziksel adanmışlık işte bizzat var olmaktır. İşe kendini fiziksel olarak adayan kişi, örgüt için pozitif etki yaratacak yenilikler ortaya koyabilmektedir. Sonuç olarak kendi geliştirdiği yeniliği uygulayarak işletmenin yenilik yapabilme potansiyeline ciddi katkı sunacaktır (Terlemez, 2012). Zihinsel adanmışlık, 
çalışanın yaptığı işin farkında olmasıdır. Zihinsel olarak devamlı hazır halde olunması durumudur. Diğer boyut olan duygusal adanmışlık boyutu ise çalışanların görevlerini yerine getirirken işiyle güçlü bağlar geliştirmesi durumu olarak ifade edilmektedir (Kurtpınar, 2011). Hem zihinsel hem de duygusal olarak işine adanmış çalışanlar, işletme için katma değer oluşturacak hizmet ya da ürün geliştirecek yenilikçi fikirler sunabilecektir. Bu durum da işletmenin stratejik yenilik kapasitesine pozitif katkı sunacaktır. Günümüz işletmelerinin başarılı olabilmeleri için kendini işine adamış çalışanlara ihtiyacı olduğu bilinen bir gerçektir. Çünkü kendini işine adayan çalışan yüksek düzeyde motivasyona sahip olacağı için işletmenin hedeflerine ulaşmasın için ciddi katkılar sunacaktır (Özkoç vd., 2018). Yapılan araştırmalar göstermektedir ki; işe adanmış çalışanlar, örgütün stratejik yenilik performansında pozitif etkiler meydana getirmiştir (Balkı, İlhan ve Özkoç, 2020; Özyılmaz ve Süner, 2015). Araştırmanın amacı doğrultusunda araştırmanın hipotezleri şu şekilde oluşmuştur:

H1: Cinsiyet değişkeni açısından stratejik yenilik yönetiminde faklılaşma vardır

H2: Cinsiyet değişkeni açısından işe adanmışlıkta faklılaşma vardır

H3: Mesleki kıdem değişkeni açısından stratejik yenilik yönetiminde faklılaşma vardır

H4: Mesleki kıdem değişkeni açısından İşe adanmışlıkta faklılaşma vardır.

H5: Stratejik yenilik yönetimi ile işe adanmışlık arasında anlamlı pozitif yönlü bir ilişki vardır.

H6: İşe adanmışlık değişkeninin stratejik inovasyon yönetimi üzerinde anlamlı bir etkisi vardır.

\section{Yöntem}

\subsection{Araştırmanın Modeli}

Araştırmada nicel araştırma modellerinden ilişkisel tarama modeli kullanılmıştır. İlişkisel tarama modeli birden fazla değişken arasındaki ilişkileri belirlemek amacıyla araştırmacıların kullandığı bir modeldir (Karasar, 2011). Bu araştırmada stratejik yenilik yönetimi ile işe adanmışlık ilişkisi incelenmiştir.

\subsection{Evren ve Örneklem}

Araştırmanın evrenini Güney Marmara Bölgesi'ndeki faaliyet gösteren 198 şirket oluşturmaktadır. Araştırmanın örneklem grubunu ise bu şirketlerden basit seçkisiz yolla seçilen 386 çalışan oluşturmaktadır. Örneklem, evrene çıkarsama yapmaya uygun özelliklere sahip olan bir alt gruptur. Örneklem seçilirken, örneklemin temsil gücüne ve yeterli büyüklükte olmasına dikkat etmek gerekmektedir (Gökçe, 1988; Lin, 1976). Örneklemin temsili olduğundan evrendeki belirli kişileri sistematik olarak dişlamıyor olması gerekmektedir. Araştırmada basit seçkisiz örnekleme yöntemi kullanılmıştır. Bu yöntemde evreni oluşturan her bireyin örneğe girme şansı eşittir (Arıkan, 2004). Araştırmanın örneklem grubu evreni temsil etmektedir. Araştırmanın örneklem grubunda yer alan bireylere ait cinsiyet ve mesleki kıdem bilgileri aşağıdaki tablolarda verilmiştir.

Tablo 1. Araştırmaya Katılanların Cinsiyetleri ile İlgili Tanımlayıcı İstatistik Analizleri

\begin{tabular}{ccc}
\hline Cinsiyet & f & $\%$ \\
\hline Kadın & 126 & 32.6 \\
Erkek & 260 & 67.4 \\
\hline
\end{tabular}

Tablo 1 incelendiğinde araştırmaya katılan çalışanların \%32.6'sının kadın, \%67.4'ünün erkek olduğu görülmektedir.

Tablo 2. Araştırmaya Katılanların Mesleki Kıdemleriyle İlgili Tanımlayıcı İstatistik Analizleri

\begin{tabular}{cccc}
\hline Mesleki Kidem & $F$ & $\%$ \\
\hline $1-5$ & 18 & 4,7 \\
$6-10$ & 72 & 18,7 \\
$11-15$ & 89 & 23,1 \\
$16-20$ & 58 & 15,0 \\
21 ve üzeri & 149 & 38,6 \\
\hline
\end{tabular}


Tablo 2 incelendiğinde araştırmaya katılan çalışanların \%4.7'sinin 1-5 yıl arası, \%18.7'sinin 6-10 yıl arası, \%23.1'inin 11-15 yıl arası, \%15'inin 16-20 yıl arası, \%38.6'sının ise 21 ve üzeri yıl kıdeme sahip olduğu görülmektedir.

\subsection{Veri Toplama Araçları}

Araştırmada Schaufeli, Salanova, Gonzalez-Roma ve Bakker (2002) tarafından geliştirilen Tecimen (2020) tarafından Türkçeye çevrilip geçerliği ve güvenirliği yapılmış olan 17 maddelik İşe Adanmışlık Ölçeği kullanılmıştır. Ölçeğin yapı geçerliğini belirlemek amacıyla yapılan analizler sonucunda [Kaiser-Meyer-Olkin $(\mathrm{KMO}=.919)$, Bartlett testi $\left.\left(\mathrm{x}^{2}=6080.831 ; \mathrm{sd}=528, \mathrm{p}=.000\right)\right]$ ölçeğin yapı geçerliğinin uygun olduğu görülmüştür. Ölçeğin, toplam varyansın 62.12'sini açıladığı; Cronbach alfa değerinin ise 0.83 olduğu görülmüştür. Bu analizler dikkate alındığında ölçeğin geçerli ve güvenilir bir ölçek olduğu görülmektedir. Ölçek; Fiziksel, Duygusal ve Bilişsel Adanmışlık olarak üç boyuttan oluşmaktadır.

Araştırmada kullanılan ikinci ölçek Mohammed (2019) tarafından geçerlik ve güvenirlik çalışmaları yapılmış Stratejik İnovasyon Ölçeği'dir. Araştırmacı tarafından faktör analizi sonucunda ölçek beş boyuta ayrılmıştır. Yapilan analizler sonucunda [Kaiser-Meyer-Olkin $(\mathrm{KMO}=.873)$, Bartlett testi $\left(\mathrm{x}^{2}=2552.982 ; \mathrm{sd}=136(\mathrm{p}=.000)\right.$ ] ölçeğin yapı geçerliğinin uygun olduğu görülmüştür. Ölçek, toplam varyansın 55.30'unu açılamaktadır. Yapılan analizlerde ölçeğin Cronbach alfa değerinin ise 0.96 olduğu görülmüştür. Yukarıdaki verilerden de anlaşılacağı üzere ölçek, geçerli ve güvenilir bir ölçektir.

\subsection{Verilerin Analizi}

Araştırmanın verilerini analiz etmeden önce verilerin normal dağılım gösterip göstermediğini test etmek amacıyla verilerin basıklık ve çarpıklık değerleri hesaplanmıştır. Analiz sonucunda veriler, normal dağılım gösterdiği için veri analizlerinde parametrik testler kullanılmıştır. Alanyazın incelendiğinde basıklık ve çarpıklık değerlerinin -2 ile +2 arasında olması gerektiği ifade edilmektedir. (Şencan, 2005). Araştırmada elde edilen verilerin analizini tapmak için tanımlayıcı istatistiksel analizleri, t-testi ve ANOVA, korelasyon ve Regresyon analizleri kullanılmıştır.

\subsection{Etik Kurulu İzni}

Çanakkale Onsekiz Mart Üniversitesi Bilimsel Araştırma Etik Kurulu 08.10.2020 tarih, 03 numaralı toplantısında (Başvuru Protokol Numarası: 2020/86) araştırmanın bilimsel etik kurallara uygun olduğu kararını vermiştir.

\section{Bulgular}

Araştırmanın bu bölümünde araştırmadan elde edilen veriler analiz edilmiştir.

Tablo 3. Stratejik İnovasyon Ölçeği Boyutlarına Ait Tanımlayıcı İstatistik Analizleri

\begin{tabular}{ccc}
\hline Ölçek Boyutları & $\overline{\mathrm{x}}$ & ss \\
\hline Yenilik Stratejisi & 4,41 &, 412 \\
Örgüt Yapısı & 4,43 &, 399 \\
İnovasyon Kültürü & 4,40 &, 462 \\
Teknoloji Yeteneği & 4,41 &, 437 \\
Müşteri ve Tedarikçilerle İlişkileri & 4,42 &, 434 \\
\hline
\end{tabular}

Tablo 3 incelendiğinde araştırmaya katılan çalışanlar; kuruluşların vizyonu ve misyonunun inovasyona bir referans içerdiğini, yenilik stratejisinin organizasyonun stratejik hedeflerine ulaşmasına yardımcı olduğunu, üretim hacminin artırılmasının süreç yeniliğinin önemli bir ölçüsü olduğunu, idari süreçlerin iyileştirilmesinin, yenilik stratejilerinin bir parçası olarak görüldüğünü, iç işbirliğinin yenilik stratejisinin uygulanmasında önemli olduğunu, müşteri memnuniyetinin yenilik stratejilerinin bir parçası olduğunu, ürün veya hizmet kalitesinin iyileştirilmesinin yenilik stratejisinin ana hedeflerinden biri olduğunu, yenilik stratejisinin oluşturulmasının, çalışanların becerilerini arttırdığını; çalışanların bağlılığını, moralini veya her ikisini de iyileştirmenin, yenilik stratejisinin bir parçası olduğunu ifade etmektedirler. Araştırmaya katılan çalışanlar, kaynakları çapraz fonksiyonlu ekiplerin kullanımına kaynak ayırdıklarını, çalışanların resmi olarak yeni teknolojilerdeki gelişmeleri izlediklerini, çalışanların başarısızlıkları öğrenme fırsatı olarak 


\section{Kasap 12/4 (2020) 4351-4364}

belgelediklerini ve kullandıklarını, yöneticilerin resmi iletişim kolaylaştırmak için sistem sağladıklarını, ilerleme durumlarını izlemek için eylem planları veya zaman çizelgeleri ve prosedürleri kullanıldığını; üst düzey yöneticinin tüm çalışanları statükoyu sorgulamaya teşvik ettiğini, düz işletme yapılarının çeşitli bakış açılarını aramayı ve bunlara dahil olmayı kolaylaştırdığını belirtmektedirler. Araştırmaya katılan çalışanlar, örgüt kültürlerinin yaratıcllı̆̆ ve inovasyona ilişkin davranışları ödüllendirdiğini, örgütlerinin kültürü resmi olmayan toplantıları ve etkileşimleri teşvik ettiğini; kültürlerinin, çalışanları kendi performanslarını izlemeye teşvik ettiğini, çalışanların yeni şeyler yapma yollarını sürekli deneyerek risk aldıklarını vurgulamışlardır. Ayrıca örgüt kültürlerinin çalışanları bilgiyi paylaşmaya teşvik ettiğini; yine ekip çalışması üzerine uzun vadeli performans odaklı olduklarını dile getirmektedirler. Araştırmaya katılan çalışanlar, rakip işletmelerin ,örgütün sahip olduğu teknolojiyle aynı veya benzer teknolojileri olduğunu, yöneticilerin paylaşım teknolojisine kaynak ayırdıklarını, iş büyümesinin bir sürücüsü olarak teknolojinin kullanımını göz önünde bulundurduğunu, teknolojik hedeflerin yeni fikirlerin değerlendirilmesine rehberlik ettiğini, çalışanların bilgi, yeni fikir ve teknolojileri araştırdıklarını, çalışanların belirli teknolojik amaç veya hedefler doğrultusunda çalıştıklarını belirtmektedirler. Rekabet avantajı için işletmenin itibarının önemli olduğunu, kuruluşun sahip olduğu teknolojinin öneminin farkında olduğunu, işletmenin rekabet avantajı için müşteri memnuniyetini önemsediğini, rekabet avantajı için şirketin ürün veya hizmet tedarikinin önemli olduğunu, tedarikçilerin kuruluşun sahip olduğu teknolojiyle aynı veya benzer teknolojilere sahip olduğunu ifade etmektedirler.

Tablo 4. İşe Adanmışlık Ölçeği Boyutlarına Ait Tanımlayıcı İstatistik Analizleri

\begin{tabular}{ccc}
\hline Ölçek Boyutları & $\overline{\mathrm{x}}$ & ss \\
\hline Fiziksel Adanmışlık & 4,43 &, 361 \\
Duygusal Adanmışlık & 4,45 &, 382 \\
Bilişsel Adanmışlık & 4,42 &, 380 \\
\hline
\end{tabular}

Tablo 4'te görüldüğü üzere araştırmaya katılan çalışanlar işteyken enerjiyle dolup taştıklarını, güçlü ve enerjik hissettiklerini, sabah uyandıklarında işe gitme isteği duyduklarını, işlerinde bir şeyler iyi gitmediğinde bile her zaman azimle devam ettiklerini vurgulamışlardır. Ayrıca işlerinde kendilerini zihinsel olarak dayanıklı hissetmekte, tek bir seferde uzun zaman dilimleri süresince çalışmayı sürdürebildiklerini ifade etmektedirler. Katılımcılar yaptıkları işi anlamlı ve amaçlarına uygun bulduklarını, iş konusunda hevesli olduklarını, işlerinin kendilerine ilham verdiklerini, yaptıkları her işle gurur duyduklarını belirtmektedirler. Çalışırken zamanın uçup gittiğini, etraflarındaki her şeyi unuttuklarını, yoğun bir şekilde çalışırken kendilerini mutlu hissettiklerini, kendilerini işe verdiklerini, kendilerini işten koparmanın güç olduğunu dile getirmektedirler.

Tablo 5. Stratejik İnovasyon Ölçeğindeki Boyutlara İlişkin Cinsiyete Göre t-testi Sonuçları

\begin{tabular}{|c|c|c|c|c|c|c|c|}
\hline Boyutlar & Cinsiyet & $\mathrm{n}$ & $\overline{\mathrm{x}}$ & ss & $\mathrm{t}$ & $\mathrm{df}$ & $\mathrm{p}$ \\
\hline \multirow{2}{*}{ Yenilik Stratejisi } & Kadın & 126 & 4,40 & ,415 & .427 & 384 & .670 \\
\hline & Erkek & 260 & 4,42 & ,411 & & & \\
\hline \multirow{2}{*}{ Örgüt Yapısı } & Kadin & 126 & 4,45 & ,431 & .702 & 384 & .483 \\
\hline & Erkek & 260 & 4,42 & ,383 & & & \\
\hline \multirow{2}{*}{ İnovasyon Kültürü } & Kadın & 126 & 4,42 & ,464 & .641 & 384 & .522 \\
\hline & Erkek & 260 & 4,38 & ,462 & & & \\
\hline \multirow{2}{*}{ Teknoloji Yeteneği } & Kadin & 126 & 4,43 & ,432 & .427 & 384 & .670 \\
\hline & Erkek & 260 & 4,41 & ,441 & & & \\
\hline \multirow{2}{*}{$\begin{array}{c}\text { Müşteri ve } \\
\text { Tedarikçilerle } \\
\text { İlişkileri }\end{array}$} & Kadın & 126 & 4,41 & ,421 & .266 & 384 & .791 \\
\hline & Erkek & 260 & 4,43 & ,440 & & & \\
\hline
\end{tabular}

Tablo 5 incelendiğinde araştırmaya katılan çalışanların cinsiyetleriyle stratejik inovasyon düzeyleri arasında anlamlı bir ilişkinin olmadığı görülmektedir. 
Tablo 6. İşe Adanmışlık Ölçeğindeki Boyutlara İlişkin Cinsiyete Göre t-testi Sonuçları

\begin{tabular}{cccccccc}
\hline Boyut & Cinsiyet & $\mathrm{N}$ & $\overline{\mathrm{x}}$ & $\mathrm{ss}$ & $\mathrm{t}$ & $\mathrm{df}$ & $\mathrm{p}$ \\
\hline \multirow{2}{*}{ Fiziksel Adanmışlık } & Kadın & 126 & 4,43 &, 343 & .111 & 201 & .911 \\
& Erkek & 260 & 4,42 &, 370 & & & \\
Duygusal Adanmışlık & Kadın & 126 & 4,44 &, 371 & .339 & 201 & .735 \\
& Erkek & 260 & 4,45 &, 389 & & & \multirow{2}{*}{384} \\
Bilişsel Adanmışlık & Kadın & 126 & 4,44 &, 414 & .688 & & \\
& Erkek & 260 & 4,41 &, 362 & & \\
\hline
\end{tabular}

Tablo 6 incelendiğinde araştırmaya katılan çalışanların cinsiyetleriyle işe adanmışlık ölçeğinde yer alan boyutlar arasında anlamlı bir ilişkinin olmadığı görülmektedir.

Tablo 7. Araştırmaya Katılan Çalışanların Mesleki Kıdemleri ile Stratejik İnovasyon Düzeyleri Arasındaki ANOVA Analizleri

\begin{tabular}{|c|c|c|c|c|c|c|c|}
\hline Boyutlar & Grup & $\mathrm{N}$ & $\overline{\mathrm{x}}$ & Ss & $\mathrm{F}$ & $\mathrm{p}$ & Anlamlı Fark \\
\hline \multirow{5}{*}{$\begin{array}{c}\text { Yenilik } \\
\text { Stratejisi }\end{array}$} & $1-5$ & 18 & 4,543 & 2949 & 3,39 & ,01 & \multirow{5}{*}{ C-D } \\
\hline & $6-10$ & 72 & 4,365 & 4040 & & & \\
\hline & $11-15$ & 89 & 4,498 & ,3235 & & & \\
\hline & $16-20$ & 58 & 4,277 & ,4636 & & & \\
\hline & 21 ve üzeri & 149 & 4,438 & ,4398 & & & \\
\hline \multirow{5}{*}{ Örgüt Yapısı } & Total & 386 & 4,419 & ,4122 & \multirow[t]{5}{*}{1,49} & \multirow[t]{5}{*}{,20 } & \\
\hline & $1-5$ & 18 & 4,515 & 2863 & & & \\
\hline & $6-10$ & 72 & 4,456 & ,4016 & & & \\
\hline & $11-15$ & 89 & 4,486 & 3490 & & & \\
\hline & $16-20$ & 58 & 4,339 & ,4656 & & & \\
\hline \multirow{5}{*}{$\begin{array}{c}\text { İnovasyon } \\
\text { Kültürü }\end{array}$} & 21 ve üzeri & 149 & 4,4190 & ,40768 & \multirow[t]{5}{*}{1,07} & \multirow[t]{5}{*}{,36 } & \\
\hline & Total & 386 & 4,434 & ,3996 & & & \\
\hline & $1-5$ & 18 & 4,314 &, 5597 & & & \\
\hline & $6-10$ & 72 & 4,395 & ,4264 & & & \\
\hline & $11-15$ & 89 & 4,471 & ,3694 & & & \\
\hline \multirow{5}{*}{$\begin{array}{l}\text { Teknoloji } \\
\text { Yeteneği }\end{array}$} & $16-20$ & 58 & 4,324 &, 5852 & \multirow[t]{5}{*}{1,40} & \multirow[t]{5}{*}{,23 } & \\
\hline & 21 ve üzeri & 149 & 4,399 & ,4628 & & & \\
\hline & Total & 386 & 4,400 & ,4626 & & & \\
\hline & $1-5$ & 18 & 4,213 & ,5138 & & & \\
\hline & $6-10$ & 72 & 4,442 & ,3638 & & & \\
\hline \multirow{5}{*}{$\begin{array}{l}\text { Müşteri ve } \\
\text { Tedarikçilerle } \\
\text { İlişkileri }\end{array}$} & $11-15$ & 89 & 4,447 & ,3913 & \multirow[t]{5}{*}{81} & \multirow[t]{5}{*}{,51 } & \\
\hline & $16-20$ & 58 & 4,364 &, 5402 & & & \\
\hline & 21 ve üzeri & 149 & 4,432 & ,4409 & & & \\
\hline & Total & 386 & 4,417 & ,4379 & & & \\
\hline & $1-5$ & 18 & 4,266 & 4498 & & & \\
\hline
\end{tabular}

A:1-5, B:6-10, C:11-15, D:16-20, E: 21 ve üzeri

Tablo 7 incelendiğinde araştırmanın örneklem grubunun mesleki kıdemleri ile stratejik inovasyon ölçeğinde yer alan örgüt yapısı ( $F=1.491 ; p>05)$, inovasyon kültürü $(F=1.076 ; p>05)$, teknoloji yeteneği $(F=1.404 ; p>05)$, müşteri ve tedarikçilerle ilişkileri $(\mathrm{F}=.818 ; \mathrm{p}>05)$ boyutları arasında anlamlı bir ilişkinin olmadığı görülmektedir. Araştırmaya katılanların mesleki kıdemleriyle yenilik stratejisi $(\mathrm{F}=3.396 ; \mathrm{p}<05)$ arasında anlamlı bir ilişkinin olduğu görülmektedir. Farklılı̆̆ın kaynağını bulmak amacıyla yapılan Tukey testi sonuçlarına göre 11-15 yıl kıdeme sahip olan çalışan ve yöneticiler, 16-20 yıl arası kıdeme sahip olanlara göre yenilik stratejisinin stratejik inovasyon konusunda önemli olduğunu belirtmektedirler. 
Tablo 8. Araştırmaya Katılan Çalışanların Mesleki Kıdemleri ile İşe Adanmışlık Düzeyleri Arasındaki ANOVA Analizleri

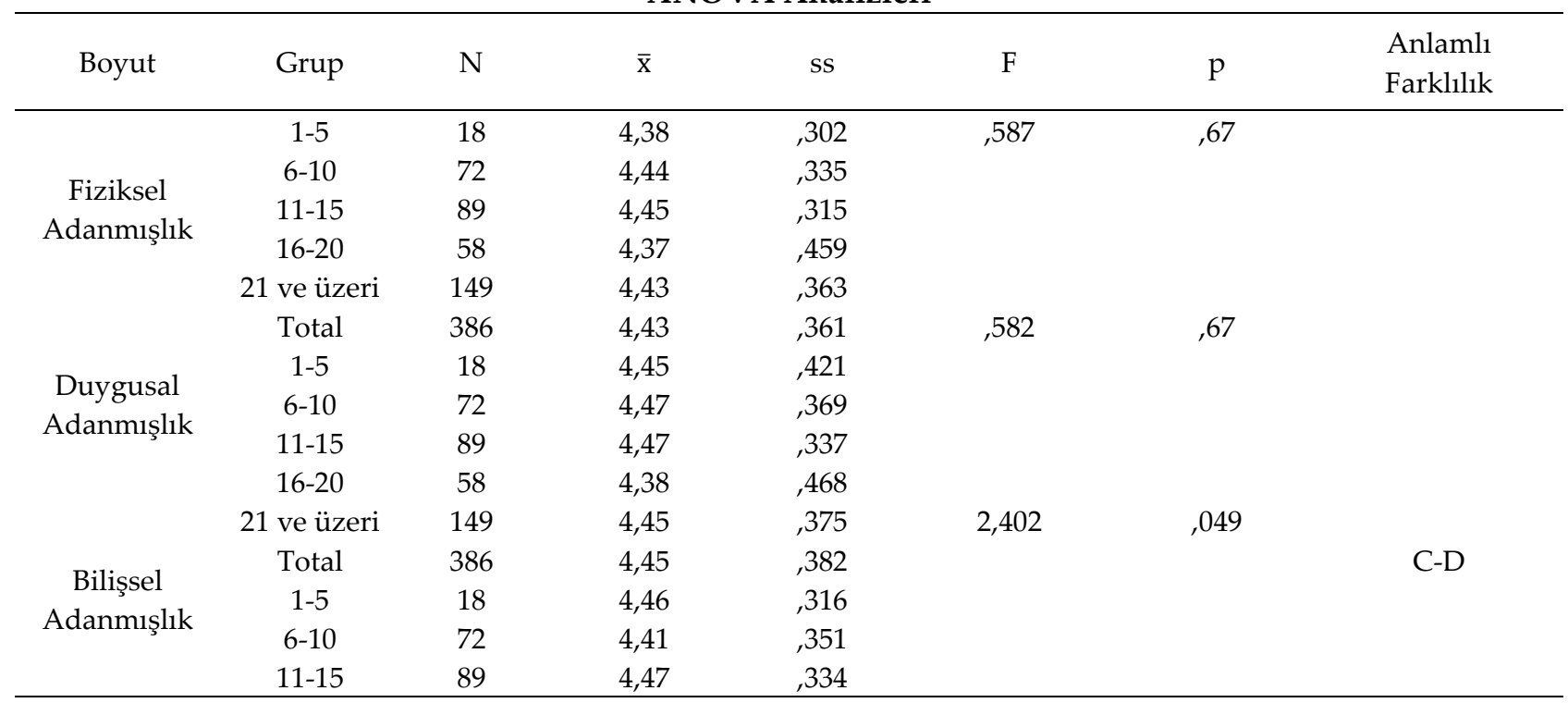

A: 1-5; B: 6-10; C: 11-15; D: 16 ve üzeri

Tablo 8 incelendiğinde araştırmaya katılan çalışanların mesleki kıdemleri ile işe adanmışlık ölçeğinde yer alan fiziksel adanmışlık ( $\mathrm{F}=0.672 ; \mathrm{p}>05)$ ve duygusal adanmışlık ( $\mathrm{F}=0.676 ; \mathrm{p}>05)$ arasında anlamlı bir ilişkinin olmadığ ${ }_{1}$ görülmektedir. Araştırma örneklem grubunun mesleki kıdemleri ile bilişsel adanmışlık boyutu ( F=2.402; p<.05) arasında anlamlı bir farklıı̆̆ğı olduğu görülmektedir. Farklılığın kaynağını bulmak amacıyla yapılan Tukey testi sonuçlarına göre 11-15 yıl arasında bu sektörde çalışanlar, 6-10 yıl arası çalışanlara göre çalışanlar göre bilişsel adanmışlığın daha önemli olduğunu ifade etmektedirler.

Tablo 9. Çalışanların Stratejik İnovasyon ve İşe Adanmışlık Düzeyleri Arasındaki İlişki

\begin{tabular}{|c|c|c|c|c|c|c|c|c|}
\hline Boyutlar & 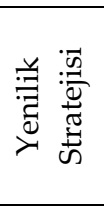 & 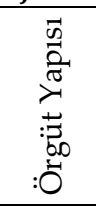 & 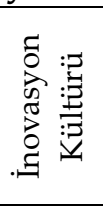 & 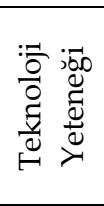 & 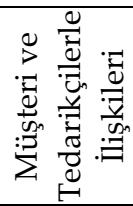 & 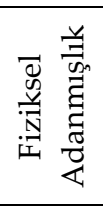 & 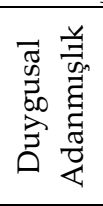 & 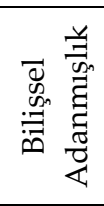 \\
\hline Yenilik Stratejisi & 1 & & & & & & & \\
\hline Örgüt Yapısı & ,635*** & 1 & & & & & & \\
\hline İnovasyon Kültürü & $499^{* *}$ &, $553^{* *}$ & 1 & & & & & \\
\hline $\begin{array}{l}\text { Teknoloji Yeteneği } \\
\text { Müşteri ve }\end{array}$ & $497^{* * *}$ &, $518^{* *}$ & ,667 & 1 & & & & \\
\hline $\begin{array}{l}\text { Tedarikçilerle } \\
\text { İlişkileri }\end{array}$ &, $508^{* *}$ &, $514^{* *}$ &, $598^{* *+}$ & ,686 & 1 & & & \\
\hline $\begin{array}{c}\text { Fiziksel } \\
\text { Adanmışlık }\end{array}$ &, $502^{* * *}$ & ,492 &, $449^{* *}$ & $466^{* *}$ &, $515^{* *}$ & 1 & & \\
\hline $\begin{array}{l}\text { Duygusal } \\
\text { Adanmışlık }\end{array}$ &, $507^{* *}$ &, $521^{* *}$ &, $523^{* *}$ &, $542^{* *}$ &, $578^{* *}$ & ,768 & 1 & \\
\hline Bilişsel Adanmışlık &, $851^{* *}$ & $868^{* *}$ &, $592^{* *}$ &, $535^{* *}$ &, $540^{* *}$ &, $514^{* * *}$ &, $520^{* *}$ & 1 \\
\hline
\end{tabular}

${ }_{* *}^{* *}<0.01$ anlamlilik seviyesinde ilişki anlaml

Tablo 9 incelendiğinde araştırmaya katılan çalışanların stratejik inovasyon ile ilgili görüşleriyle işe adanmışlık ile ilgili görüşleri arasında pozitif yönlü yüksek düzeyde bir ilişkinin olduğu görülmektedir. Tabloya göre yenilik stratejisi ve örgüt yapısı ile bilişsel adanmışlık arasında yüksek düzeyde pozitif yönlü, yenilik strateji ve örgüt yapısı ile fiziksel ve duygusal adanmışlık arasında orta düzeyde pozitif yönlü bir ilişkinin olduğu görülmektedir. İnovasyon kültürü, teknoloji yeteneği, müşteri ve tedarikçilerle ilişkileri ile fiziksel, duygusal ve bilişsel adanmışlık arasında orta düzeyde pozitif yönlü bir ilişkinin olduğu görülmektedir. 
Tablo 10. Stratejik İnovasyonun İşe Adanmışlık Düzeyine göre Yordanmasına İlişkin Regresyon Analizi

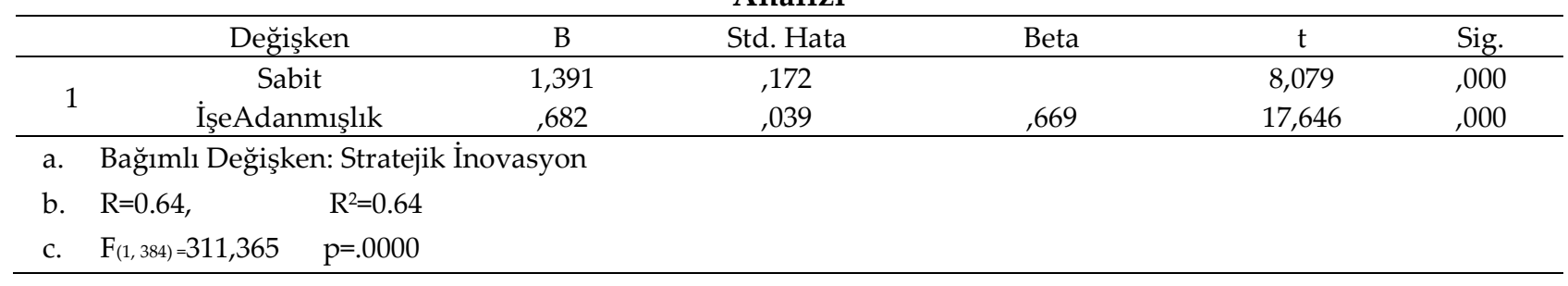

Tablo 10 incelendiğinde yapılan basit doğrusal regresyon analizi sonucunda işe adanmışlıkla stratejik inovasyon arasında anlamlı bir ilişki olduğu görülmüş $\left(R=0.64, R^{2}=0.64\right)$, işe adanmışlı̆ı̆ın stratejik inovasyona

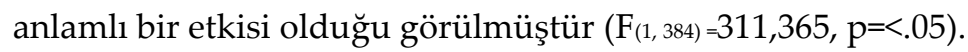

\section{Sonuç ve Tartışma}

Araştırmaya katılan çalışanların yenilik stratejisi, örgüt yapısı, inovasyon kültürü, teknoloji yeteneği, müşteri ve tedarikçilerle ilişkiler konusunda olumlu düşündükleri görülmektedir. Araştırma katılımcıları stratejik hedeflere ulaşmada, üretim hacminin artırılmasında, idari süreçlerin iyileştirilmesinde, ürün veya hizmet kalitesinin iyileştirilmesinde yenilik stratejilerinin önemli olduğunu vurgulamışlardır. Yenilik stratejilerinin işgörenlerin yeteneklerini, bağlılıklarını, motivasyonlarını artırdığını belirtmektedirler. Araştırmaya katılan çalışanların, başarısızlıkları öğrenme fırsatı olarak gördüklerini, teknolojideki yeni gelişmeleri izlediklerini, resmi iletişimi kolaylaştırmak amacıyla çalışma yapıldığını, ilerleme eylem planlarının olduğunu ifade etmektedirler. Ayrıca katılımcıların yaratıcılığa ve inovasyona ilişkin davranışlara olumlu yaklaşıldığını, çalışanların kendi performanslarını izlediğini, resmi olmayan toplantıların teşvik edildiğini, bilginin paylaşıldığını, ekip çalışmasının öneminin vurgulandığını dile getirmektedirler. Araştırma katılımcıları, yöneticilerin teknolojik hedeflerin yeni fikirlerin değerlendirilmesine rehberlik ettiğini, işletmenin itibarının önemli olduğunu, tedarikçilerin ve müşterilerin bu süreçte önemli olduklarını belirtmektedirler. Ayrıca katılımcılar fiziksel olarak enerji dolu olduklarını, zihinsel olarak kendilerini dayanıklı hissettiklerini, işlerinin kendilerine gurur verdiklerini, çalışırken zamanın nasıl geçtiğini anlayamadıklarını belirtmektedirler. Stratejik yenilik yönetmiyle ilgili alanyazında araştırmalarda bu araştırmayı destekleyen bulgulara rastlanmıştır (Cormican ve O'sullgvan, 2004; Çetinkaya ve Gülbahar, 2019; Keupp, Palmie ve Gassman, 2012; Pınar, Kamaşak ve Bulutlar, 2009; Rothwell ve Gardiner, 1989). Bonnici ve Paroutis (2013) çalışmalarında stratejik yönetim süreçlerinin inovasyonu olumlu etkilediğini belirtmişlerdir. Drejer (2006) stratejik yönetimin ve inovatif düşünce yapısının işletmelerce uygulanmasının işletmelerin daha iyi yönetilebilmesi adına önemli olduğunu dile getirmiştir.

Araştırma örneklem grubunun cinsiyetleriyle stratejik inovasyon ve işe adanmışlık düzeyleri arasında anlamlı bir ilişkinin olmadığı görülmektedir. Araştırmaya katılanlarınların mesleki kıdemleriyle yenilik stratejisi arasında bir ilişkinin olduğu görülmektedir. 11-15 yıl kıdeme sahip olan çalışan ve yöneticiler, 16-20 yıl arası kıdeme sahip olanlara göre yenilik stratejisinin stratejik hedeflere ulaşmada, idari süreçlerin başarıya ulaşmasında, iç işbirliğinde, müşteri memnuniyetinde, ürün veya hizmet kalitesinin iyileştirilmesinde önemli olduğunu ifade etmektedirler. Araştırmanın katılımcılarının mesleki kıdemleri ile bilişsel adanmışlık boyutu arasında bir farklılığın olduğu görülmektedir. 11-15 yıl arasında bu sektörde çalışanlar, 6-10 arası çalışanlara göre çalışırken zamanın hızlı geçtiğini, yoğun bir şekilde çalışırken kendilerini mutlu hissettiklerini, kendilerini işlerine verebildiklerini dile getimektedirler. Araştırmaya katılan çalışanların stratejik inovasyon ile ilgili görüşleriyle işe adanmışlık ile ilgili görüşleri arasında pozitif yönlü yüksek düzeyde bir ilişkinin olduğu görülmektedir. İşe adanmışlıkla stratejik inovasyon arasında anlamlı bir ilişki olduğu, işe adanmışlığın stratejik inovasyonun anlamlı bir yordayıcısı olduğu görülmüştür. Benzer araştırmalarda; işe adanmış çalışanların örgütün stratejik yenilik performansında pozitif etkiler meydana getirdiği vurgulanmaktadır (Balkı, İlhan ve Özkoç, 2020; Özyılmaz ve Süner, 2015). Başka bir araştırmada çalışanların kurumda teknoloji kullanımlarının, teknolojiye yönelik ilgilerinin ve kendileri için teknoloji algılarının, dijital teknolojideki yetkinliklerinin, eğlence amaçlı ve bilinçli kullanımlarının görev performanslarını etkilediği tespit edilmiştir (İrge ve Şen, 2020).

Örgütlerin stratejik yenilik yönlerini geliştirmesi, aslında günümüz rekabet koşulları göz önüne alındığında olmazsa olmazdır. Çalışmada da işletme paydaşları yeniliğin önemli olduğunu vurgulamışlardır. Çünkü 


\section{Kasap 12/4 (2020) 4351-4364}

değişimin ve gelişimin hızı işletmelerin durağanlıklarını imkânsız hale getirmiştir. Bu bağlamda stratejik yenilik özelliği taşıyan işletmelerin de rakiplerine oranla daha avantajlı duruma geçeceği aşikardır. Bu yüzden stratejik yenilik rekabet edebilirlikte belirleyici unsur olarak bulunmaktadır. Ayrıca iş görenlerin yenilik yapabilmesi örgüt kültürünün yeniliğe uygun olmasıyla mümkündür. Yöneticilerin örgüt kültürünün gücünün farkında olması önemlidir (Özkan Canpolat, Erenler Tekmen ve Bereha, 2020). Örgüt kültürü çalışanlarına sağlıklı bir iş ortamı sağlarsa bu örgütte işe adanmışlık söz konusu olabilir. İşe adanmışlık örgüt performansına önemli katkılar sunacaktır. Çünkü işe adanmış çalışanlar işletmedeki diğer çalışanlara oranla daha yüksek verimlilikte çalışmaktadır. Yine işe adanmış çalışan kişisel gelişimine önem verdiği için yenilikleri takip ederek örgütün amaçlarına ulaşmasında fark yaratacak etkiyi sergileyeceklerdir (Yıluzar, 2016). Bundan ötürü işine kendini adamış bir çalışanın yeniliklere açık hale geleceği ve işletmedeki diğer çalışanlardan daha verimli bir performans göstereceği bilinmektedir. Özyılmaz ve Süner (2015) işe adanmışlığın, çalışanın iş tatmini ve örgütsel bağlılığı üzerinde pozitif ve anlamlı bir ilişkisi olduğu tespit edilmiştir. Kalay vd. (2015) araştırmasında inovasyon stratejisi ve örgüt yapısının inovasyon performansı üzerinde pozitif yönde etkili olduğu tespit edilmiştir.

$\mathrm{Bu}$ araştırmada literatürdeki diğer çalışmalarla örtüşmektedir. Araştırmanın bulguları stratejik yenilik yönetiminin işe adanmışlık ile güçlü bir bağının olduğunu ortaya koymaktadır. Ayrıca araştırmada stratejik yenilik yönetiminin çalışanlar üzerinde önemli bir etkisinin olduğu görülmüştür. Çalışmanın bulguları yöneticilere bir yol haritası sunmaktadır. Çünkü yeniliğe önem vermenin ne derece kıymetli olduğu çalışma sayesinde yöneticilere bildirilmektedir. Alan yazında iki konu başlı̆̆ının birlikte ele alındığı bilimsel yayın sınrlı olduğu için bu eksikliğin doldurulacağı düşünülmestedir.

\section{Kaynakça}

Akgemcï, T., Öğüt, A. ve Ay Tosun, M. (2005). Küresel rekabetin sunduğu fırsatlar ve tehditler bağlamında kobilerde stratejik yenilik yönetimi swot analizine dayalı kuramsal bir değerlendirme. SÜ İ̈BF Sosyal ve Ekonomik Araştırmalar Dergisi, 5(10), 139-156.

Altınkurt, Y. (2007). Eğitim örgütlerinde stratejik liderlik ve okul müdürlerinin stratejik liderlik uygulamaları (Yayınlanmamış Doktora Tezi). Anadolu Üniversitesi Eğitim Bilimleri Enstitüsü, Eskişehir.

Arıkan, R. (2004). Araştırma teknikleri ve rapor hazırlama. Ankara: Asil Yayıncılık.

Atherton, A. ve Hannon, P. D. (2000). Innovation processes and the small business: a conceptual analysis. International Journal of Business Performance Management, 2(4), 276-292.

Aydın, A. Ö. ve Bekmezci, M. (2020). Stratejik yönetim anlayışında yenilik ve yenilik yönetiminin örgütler için rekabet üstünlüğü sağlamadaki etkisine yönelik değerlendirme. Türkiye Mesleki ve Sosyal Bilimler Dergisi, (3), 86-106.

Balkı, S., İlhan, İ. ve Özkoç, A. G. (2020). Mutfak çalışanlarında algılanan dışsal prestij ve işe adanmışlığının yenilik performansına etkisi: Nevşehir ilinde bir uygulama. Ömer Halisdemir Üniversitesi İktisadi ve İdari Bilimler Fakültesi Dergisi, 13(3), 401-412.

Bielinis, S. (2004). Innovative centres and SME's as vehicles in regional development. Review of Studies, Seagull Report 4.

Bonnici, T. S. ve Paroutis, S. (2013). Developing a dominant logic of strategic innovation. Management Research Review, 36(10), 924-938.

Bostancı, H. ve Ekiyor, A. (2015). Çalışanların işe adanmasının örgüt içi girişimciliğe etkisinin incelenmesi: Sağlık sektöründe bir uygulama. Uluslararası Sağlık Yönetimi ve Stratejileri Araştırma Dergisi, 1(1), 3751.

Cormican, K. ve O'sullgvan, D. (2004). Auditing best practice for effective product innovation management. Technovation, 24(10), 819-829.

Çetinkaya, F. F. ve Gülbahar, O. (2019). Stratejik yönetim ve inovasyon ilişkisi: KOBİler üzerine bir araştırma. Ahi Evran Üniversitesi Sosyal Bilimler Enstitüsü Dergisi, 5(2), 349-367. 


\section{Kasap 12/4 (2020) 4351-4364}

Deniz, M. (2011). Kobilerde yenilik, yenilik stratejileri ve bir uygulama. SÜ İ̈BF Sosyal ve Ekonomik Araştırmalar Dergisi. 11(22), 141-175.

Drejer, A. (2006). Strategic innovation: a new perspective on strategic management. Handbook of Business Strategy, 7(1), 143-147.

Esen, E. 2011. Çalışanların örgüte cezbolması. Marmara Üniversitesi İ.I.B.F. Dergisi, 30(1), 377-390.

Gökçe, B. (1988). Toplumsal bilimlerde araştırma. Ankara: Savaş Yayınları.

Gray, C. and Allan, J. (2001). Advanced use of ICT and networking: Tomorrow's signs of entrepreneurship in SMEs?". 31st European Small Business Seminar 20012001 An Enterprise Odyssey The Link Between Education, Enterprise and Technology in the New Millennium, September 12-14, Dublin.

Güçlü, N. (2003). Stratejik yönetim. Gazi Ĕ̆itim Fakültesi Dergisi, 23(2), 61-85.

Güleş, H. K. ve Bülbül, H. (2004), Yenilikçilik (2. Baskı). Ankara: Nobel Yayıncllık.

Harzer, C. ve Ruch, W. (2014). The role of character strengths for task performance, job dedication, interpersonal facilitation, and organizational support. Human Performance, 27(3), 183-205.

İrge, T. N. ve Şen, E. (2020). Çalışanların dijital teknolojiye yönelik tutumlarının ve iç girişimcilik özelliklerinin bireysel iş performanslarına etkisi. İşletme Araştırmaları Dergisi, 12(3), 2556-2579. https://doi.org/10.20491/isarder.2020.993

Kahn, W. A. (1990). Psychological conditions of personal engagement and disengagement at work. The Academy of Management Journal, 33(4), 692-724.

Kahn, W. A. (1992). To be fully there: Psychological presence at work. Human Relations, 45(4), 321-349.

Kalay, F., Tuncer, C. O., Kızıldere, C. ve Arslan Kalay, H. (2015). Stratejik inovasyon yönetimi uygulamalarının firma inovasyon performansı üzerindeki etkileri. Bilgi Ekonomisi ve Yönetimi Dergisi, X(II), 67-77.

Kale E. (2010). Konaklama işletmelerinde örgüt içi faktörlerin yenilik ve yaratıcllık performansına etkileri (Yayımlanmamış Doktora Tezi). Erciyes Üniversitesi, Sosyal Bilimler Enstitüsü, Kayseri.

Karasar, N. (2011). Bilimsel araştırma yöntemleri. Ankara: Nobel Yayıncılık.

Karataş, M. T. ve Aktaş, H. (2019). İşe adanmışlık, iş becerikliliği ve iş gören performansı etkileşimi: Havacılık sektöründe bir araştırma (Yayımlanmamış Yüksek Lisans Tezi). Bahçeşehir Üniversitesi Sosyal Bilimler Enstitüsü, İstanbul

Kendir, H., Arslan, E. ve Özçelik Bozkurt, H. (2018). Devam bağlılığı, presenteeism ve işten ayrılma niyeti arasındaki ilişki: Beş yıldızlı otel işletmelerinde bir araştırma, İşletme Araştırmaları Dergisi, 10(4), 1029-1046. http://dx.doi.org/10.20491/isarder.2018.561

Keupp, M. M., Palmié, M. and Gassmann, O. (2011). The strategic management of innovation: A systematic review and paths for future research. International Journal of Management Reviews, 14, 367-390.

Kurtpınar M. (2011). Birey-örgüt uyumunun bireysel performans üzerindeki etkisinde kişilik özellikleri ve işe adanmışlı̆̆ın rolü (Yayımlanmamış Yüksek Lisans Tezi). Genelkurmay Başkanlığı, Harp Akademileri Komutanlığı, Stratejik Araştırmalar Enstitüsü, İstanbul.

Lin, N. (1976). Foundations of social research. McGraw-Hill, USA.

May D. R., Richard L. Gilson ve Lynn M. Harter, (2004,). The psychological conditions of meaningfulness, safety and availability and the engagement of the human spirit at work, Journal of Occupational and Organizational Psychology, 77(1), 29-30.

Mert, G. (2020). Kurumların stratejik yönetim süreçlerinde dijitalleşmenin rolü. International Journal of Socıal, Humanttes and Administrative Sciences, 6(22). 41-58.

Mohammed, W. (2019). Stratejik itici güçlerin örgüt performansı ve stratejik yenilik yönetimine etkisinde işletme yaşı ve büyüklü̆̆̈̈nün düzenleyici rolü: Etiyopya'da bir araştırma (Yayımlanmamış Doktora Tezi). İstanbul Üniversitesi Sosyal Bilimler Enstitüsü, İstanbul. 


\section{Kasap 12/4 (2020) 4351-4364}

Örücü, E., Kılıç, R. ve Savaş, A. (2011). KOBİlerde inovasyon stratejileri ve inovasyon yapmayı etkileyen faktörler: Bir Uygulama. Doğuş Üniversitesi Dergisi, 12(1) 58-73.

Özaydın, G. ve Çelik, Y. (2020). Liderlik tarzları ve görev performansının tarım işletmelerinde yenilik stratejileri üzerine etkisi (Çumra İlçesi Örneği). Kahramanmaraş Sütçü İmam Üniversitesi Tarım ve Doğa Dergisi, 23(1), 181-193.

Özbağ K. G. (2010). Temel yetenek tabanlı yönetim modelinin yenilik performansına etkileri üzerine bir araştırma (Yayımlanmamış Doktora Tezi). Kocaeli Üniversitesi, Sosyal Bilimler Enstitüsü, Kocaeli.

Özkan Canpolat, E., Erenler Tekmen, E. ve Bereha, A. (2020). Örgüt kültürünün motivasyon üzerindeki etkisinin doğrusal ve bulanık mantık yöntemleriyle değerlendirilmesi. İsletme Araştırmaları Dergisi, 12(3), 2246-2259. http://dx.doi.org/10.20491/isarder.2020.974

Özkoç, A. G., Kendir, H., Arslan, E. ve Özgün, N. (2019). İşgörenlerin nepotizm ve sinizm algıları arasındaki ilişki: Nevşehir'deki otel işletmelerinde bir araştırma. İşletme Araştırmaları Dergisi, 11(4), 2960 - 2971. http://dx.doi.org/10.20491/isarder.2019.787

Özyılmaz A. ve Süner Z. (2015). İşe adanmışlığın işyeri tutumlarına etkisi: Hatay'daki 9 işletmede yapılan ampirik araştırmanın sonuçları. Eskişehir Osmangazi Üniversitesi İ̈BF Dergisi, 10(3), 143-164.

Pınar, İ., Kamaşak, R. ve Bulutlar, F. (2009). Strateji geliştirme süreçlerinin yenilikçilik üzerinde etkisi. 21-23 Mayıs 17. Ulusal Yönetim ve Organizasyon Kongresi, (ss. 399-404). Eskişehir.

Porter, M. E. (1981). The contributions of industrial organization to strategic management. Academy Of Management Review, 6(4), 609-620.

Rich BL., Lepine J. A. ve Crawford E. R. (2010). Job Engagement: Antecedents and Effects on Job Performance. The Academy of Management Journal, 53(3), 617-635. https://doi.org/10.5465/amj.2010.51468988

Rothwell, R. and Gardiner, P. (1989). The strategic management of re-innovation. RED Management, 19(2), 147160.

Schaufeli W. B, Salanova, M., Gonzalez-Roma, V. ve Bakker, A. B. (2002). The measurement of engagement and burnout: A two sample confirmatory factor analytic approach. Journal of Happiness Studies, 3(1).

Shıbu, A. A. ve Uysal, G. (2020). Kobilerde Örgütsel Yenilik ve Örgütsel Yaratıcllı Stratejileri: Dönüşümcü Liderlik Etkisi. Avrasya Sosyal ve Ekonomi Araştırmaları Dergisi, 7(2), 41-49.

Şencan, H. (2005). Sosyal ve davranışsal ölçümlerde güvenilirlik ve geçerlilik. Ankara: Ocak Yayınları.

Tecimen, M. (2020). Yöneticiye duyulan güvenin işe adanmışlı ve örgütsel vatandaşlık davranışı üzerindeki etkisi (Yayımlanmamış Doktora Tezi). Kırıkkale Üniversitesi Sosyal Bilimler Enstitüsü, Kırıkkale.

Terlemez A. G. (2012). İşveren markasının, işe adanmışlık ve işten ayrılma niyeti ile ilişkisinde örgütsel çekiciliğin rolü: Türk hava yolları örneği (Yayımlanmamış Yüksek Lisans Tezi). Genelkurmay Başkanlığı Harp Akademileri Komutanlığı, Stratejik Araştırmalar Enstitüsü. İstanbul.

Uysal, B., Özçelik, G. ve Uyargil, C. B. (2018). Bireysel iş yapılandırmanın sonuçları: Bireysel iş yapılandırmanın psikolojik sermaye ve işe adanmışlık üzerindeki etkisinin değerlendirilmesi. Yönetim Bilimleri Dergisi, 16(32), 651-666.

Ventura, K. ve Soyuer, H. (2016). İşletmelerde Yenilik Yönetimi ve Araştırma Geliştirme-Pazarlama-Üretim Entegrasyonunda Bilgiye Dayalı Yenilik Yaklaşımı. Ege Academic Review, 16, 41-50.

Yıluzar H. (2016). Kişi-Örgüt uyumu ile işe adanmışlı ve örgütsel bağglllk ilişkisi: Sağlık sektöründe bir araştırma (Yayınlanmamış Yüksek Lisans Tezi). Akdeniz Üniversitesi, Sosyal Bilimler Enstitüsü, Antalya. 
Ek 1 - Stratejik Yenilik Yönetimi Ölçeği

1: Kesinlikle Katılmıyorum, 2: Katılmıorum, 3: Orta Düzeyde Katılıyorum, 4: Katılıyorum, 5: Kesinlikle Katiliyorum.

\begin{tabular}{|c|c|c|c|c|c|}
\hline Yenilik Stratejisi & 1 & 2 & 3 & 4 & 5 \\
\hline 1. Kuruluşların vizyonu veya misyonu, inovasyona bir referans içerir. & & & & & \\
\hline 2. Yenilik stratejisi, organizasyonun stratejik hedeflerine ulaşmasına yardımcı olmuştur. & & & & & \\
\hline 3. Üretim hacmimizin artırılması, süreç yeniliğinin önemli bir ölçüsüdür. & & & & & \\
\hline 4. İdari süreçlerin iyileştirilmesi, yenilik stratejimizin bir parçası olarak görülüyor. & & & & & \\
\hline 5. İç işbirliği, yenilik stratejisinin uygulanmasının önemli bir parçasıdır. & & & & & \\
\hline 6. Müşteri memnuniyeti, yenilik stratejimizin bir parçasıdır. & & & & & \\
\hline $\begin{array}{l}\text { 7. Ürün veya hizmet kalitesinin iyileştirilmesi yenilik stratejisinin ana hedeflerinden } \\
\text { biridir. }\end{array}$ & & & & & \\
\hline 8. Yenilik stratejisinin oluşturulması, çalışanların becerilerini arttııır. & & & & & \\
\hline $\begin{array}{l}\text { 9. Çalışanların bağlılığını, moralini veya her ikisini de iyileştirmek, yenilik stratejisi } \\
\text { izlememizin bir parçasıdır. }\end{array}$ & & & & & \\
\hline Örgüt Yap1sı & 1 & 2 & 3 & 4 & \\
\hline
\end{tabular}

10. Yöneticiler, kaynakları çapraz fonksiyonlu ekiplerin kullanımına resmen kaynak ayıriyor

11. Çalışanlar resmi olarak yeni teknolojilerdeki gelişmeleri izliyor.

12. Çalışanlar, başarısızlıkları öğrenme fırsatı olarak belgeliyor ve kullanıyor.

13. Yöneticiler resmi iletişim kolaylaştırmak için sistem sağlar.

14. İlerleme durumunu izlemek için eylem planları veya zaman çizelgeleri ve prosedürleri kullanılır.

15. Üst düzey yönetici, tüm çalışanları statükoyu sorgulamaya teşvik eder.

16. Düz işletme yapımız çeşitli bakış açılarını aramayı ve bunlara dahil olmayı kolaylaştırır.

\section{İnovasyon Kültürü}

17. Kültürümüz yaratıcılı̆̆a ve inovasyona ilişkin davranışları ödüllendiriyor.

18. Örgütümüzün kültürü resmi olmayan toplantıları ve etkileşimleri teşvik eder.

19. Kültürümüz çalışanları kendi performansların izlemeye teşvik eder.

20. Çalışanlar, yeni şeyler yapmanın yollarını sürekli deneyerek risk alırlar.

21. Kültürümüz, çalışanları bilgiyi paylaşmaya teşvik eder.

22. Kültürümüz ekip çalışması üzerine uzun vadeli performans odaklıdır.

\section{Teknoloji Yeteneği}

23. Yarışmacılar, kuruluşun sahip olduğu teknolojiyle aynı veya benzer teknolojileri vardır.

24. Yöneticiler paylaşım teknolojisine kaynakları ayırıyor.

25. İş büyümesinin bir sürücüsü olarak teknolojinin kullanımını göz önünde bulundurur.

26. Teknolojik hedefler, yeni fikirlerin değerlendirilmesine rehberlik eder.

27. Çalışanlar bilgi, yeni fikir ve teknolojileri araştırıyor.

28. Çalışanlar belirli teknolojik amaç veya hedefler doğrultusunda çalışırlar.

\section{Müşteri ve Tedarikçilerle İlişkileri}

29. Rekabet avantajı için işletmenin itibarı önemlidir.

30. Müşterilerin, kuruluşun sahip olduğu teknolojiyle aynı veya benzerleri teknoloji vardır.

31. İşletmenin rekabet avantajı için Müşteri memnuniyeti önemlidir.

32. Rekabet avantajı için şirketin ürün veya hizmet tedariki önemlidir.

33. Tedarikçilerin, kuruluşun sahip olduğu teknolojiyle aynı veya benzer teknolojilere sahiptir. 
Ek 2 - İşe Adanmışlık Ölçeği

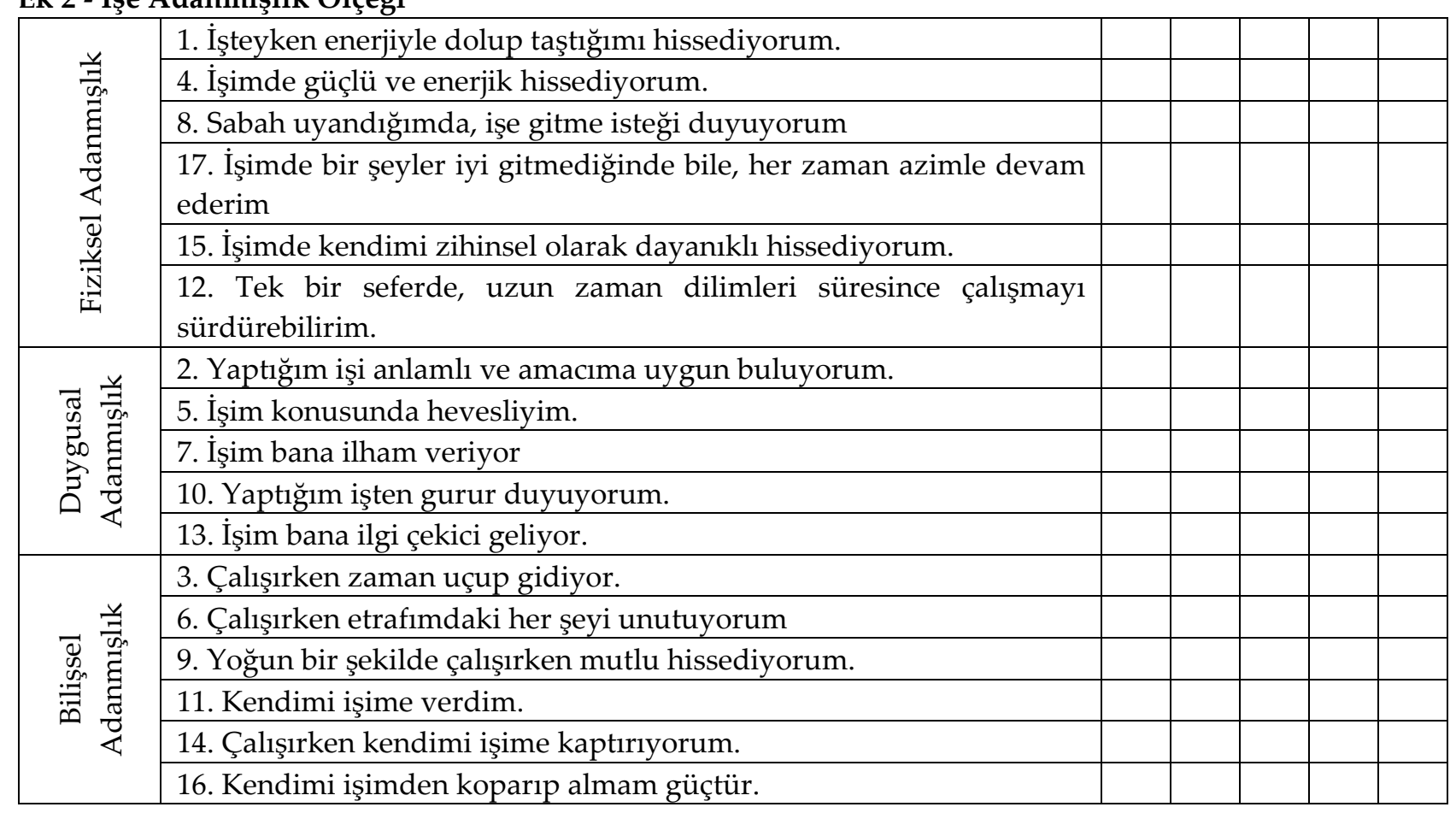

Ek 3 - Etik Kurul Belgesi

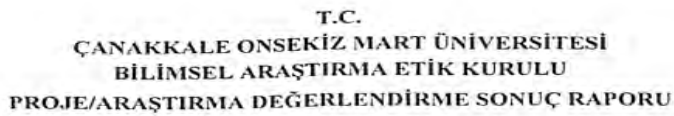

\begin{tabular}{|c|c|}
\hline Toplantı Tarihi & 08.10 .2020 \\
\hline Toplantı Sayısı & 03 \\
\hline Başvuru Protokol Numarast & $2020 / 86$ \\
\hline Başvuru Tarihi & 23.09 .2020 \\
\hline Proje/Araşturma Başlığı & $\begin{array}{l}\text { Stratejik Yenilik Yönetiminin Çalışanların Işe } \\
\text { Adanmıșlıs̆ma Etkisi }\end{array}$ \\
\hline Proje/Araştırma Yürütücüsü & Ögr. Gör. Dr. Mesut KASAP \\
\hline Karar & Bilimsel Araştırma Etik Kurallarına uygundur. \\
\hline Açıklamalar & - \\
\hline
\end{tabular}

